\title{
Comparison of Microbial Fungicides in Antagonistic Activities Related to the Biological Control of Phytophthora Blight in Chili Pepper Caused by Phytophthora capsici
}

\author{
Sang Gyu Kim ${ }^{1}$, Yelim Jang ${ }^{1}$, Hye Young Kim ${ }^{1}$, Young Jin Koh ${ }^{2}$ and Young Ho Kim ${ }^{1 *}$ \\ ${ }^{1}$ Department of Agricultural Biotechnology, Seoul National University, Seoul 151-921, Korea \\ ${ }^{2}$ Department of Plant Medicine, Sunchon National University, Suncheon 540-742, Korea
}

(Received on August 3, 2010; Accepted on October 10, 2010)

Two similar microbial fungicides (termed as MA and MB) developed in a Korean biopesticide company were analyzed and compared each other in their biocontrol activities against the phytophthora blight of chili pepper caused by Phytophthora capsici. MA and MB contained the microbe Paenibacillus polymyxa and Bacillus subtilis, respectively, with concentrations over those posted on the microbial products. In comparison of the isolated microbes (termed as MAP from MA and MBB from MB) in the antagonistic activities against $P$. capsici was effective, prominently against zoospore germination, while MBB only significantly inhibited the mycelia growth of the pathogen. Some effectiveness of MAP and MBB was noted in the inhibition of zoosporangium formation and zoospore release from zoosporangia; however, no such large difference between MAP and MBB was noted. In a pot experiment, MA reduced the severity of the phytophthora blight more than MB, suggesting that the disease control efficacy would be more attributable to the inhibition of zoospore germination than mycelia growth of $P$. capsici. These results also suggest that the similar microbes $\mathrm{MA}$ and $\mathrm{MB}$ targeting different points in the life cycle of the pathogen differ in the disease control efficacies. Therefore, to develop microbial fungicides it is required to examine the targeting points in the pathogen's life cycle as well as the action mode of antagonistic microorganisms.

Keywords : biocontrol, chili pepper, microbial fungicides, Phytophthora capsici

Phytophthora blight of chili pepper caused by Phytophthora capsici is a serious disease in the crop cultivation, of which the main control measures include fungicide spray and cultural practices such as crop rotation (Hwang, 2002; Hwang and Kim, 1995; Ristano and Johnston, 1999). Several fungicides including metalaxyl, oxadixyl, propamocarb,

\footnotetext{
*Corresponding author.

Phone) +82-2-880-4675, FAX) +82-2-873-2317

E-mail)yhokim@snu.ac.kr
}

copper oxychloride, chlorothalonil, dithianone, etc. are available, but it is very difficult for them to exert their efficacy in controlling the disease because of the soilborne nature and exceedingly rapid spread of the disease (Hwang, 2002; Kim, 2004). Crop rotation also is not capable of exerting sufficiently effective controlling of the disease because the pathogen survives as oospores (primary inoculum) in soil without host plants for several years (Hwang and Kim, 1995). It is necessary to develop alternative strategies for the control of the phytophthora blight of chili pepper. Use of antagonistic microbes as biological control agents (BCAs) is suggested as a good way to cope with this kind of disease problem (Hwang, 2002).

Over a hundred microbial products are currently registered or marketed as BCAs worldwide (Whipps and McQuiken, 2009), and presently a total of 14 microbial fungicides are commercially registered in Korea. However, inconsistency in the efficacy of BCAs in large-scale glasshouse or field conditions is one of major constraints in biological disease control (Whipps and McQuiken, 2009). This kind of problem may also hold true to the above microbial fungicides marketed in Korea, especially those for targeting soil-borne pathogens, for which crop growers are not convinced of their practical usage in large-scale crop plantations. Therefore, every possible way should be sought to increase efficacy and consistency of BCAs even after their commercialization in the market.

Selection of good antagonists and their characterization such as mode of actions are important processes and criteria for the successful development of BCAs (Whipps and Davies, 2000). Especially the understanding on the action mode (mechanism) of BCAs in the biological control may provide crucial information that can be used for practical applications of BCAs, promoting their consistent control efficacy. In this study, two similar microbial fungicides registered and marketed in Korea (both targeting Phytophthora spp.) were compared in antagonistic mechanisms and biological control efficacies against the phytophthora blight of chili pepper caused by $P$. capsici to examine their relations in the biological control. 


\section{Materials and Methods}

Pathogen and microbial fungicides. An isolate of Phytophthora capsici, which had been used in previous studies (Kim and Kim, 2009; Kim et al., 2009), was used in this study. The pathogen was grown on V8 juice agar $(100 \mathrm{ml}$ of V8 juice, $900 \mathrm{ml}$ of distilled water, $1 \mathrm{~g}$ of $\mathrm{CaCO}_{3}, 15 \mathrm{~g}$ of agar). The microbial fungicides used in this study were two products developed and commercialized by a Korean biopesticide company, which were hereby termed as MA and $\mathrm{MB}$, containing Paenibacillus polymyxa and Bacillus subtilis as their microbial agents, respectively. The microbial concentrations marked on the products were $5 \times 10^{6}$ colony forming units $(\mathrm{CFU}) / \mathrm{ml}$ for $\mathrm{MA}$ and $1 \times 10^{7} \mathrm{CFU} / \mathrm{ml}$ for $\mathrm{MB}$, respectively. MA is used for the control of the phytophthora blight of chili pepper (Capsicum annuum) and the powdery mildew of cucumber (Cucumis sativus), while MB for the control of the phytophthora rot of common fig (Fiscus carica) and the grey mold of tomato (Lycopersicon esculentum).

Evaluation of the microbial fungicide commodities. The microbes (bacterial isolates) in the microbial products were identified and their population densities were examined to evaluate their appropriateness as microbial commodities marked on the products.

Identification of the bacterial isolates was conducted by the analysis of $16 \mathrm{~S}$ ribosomal DNA (rDNA) sequencings. For this, the single-colony isolates of the bacteria obtained from MA and MB by the dilution pour plate method were cultured in brain heart infusion (BHI) (Conda, Madrid, Spain) broth at $28^{\circ} \mathrm{C}$ for 2 days with shaking at 200 RPM. Genomic DNAs of the bacterial isolates were prepared using a Wizard DNA purification kit (Promega Corp., Madison, WI, USA), and their 16S rDNA were amplified by polymerase chain reaction (PCR) using the primers of 27mF (5'-AGAGTTTGATCMTGGCTCAG-3') and 1492mR (5'-GGYTACCTTGTTACGACTT-3') (Brosius et al., 1978; Weisburg et al., 1991) in AccuPowerTM PCR premix (Bioneer Corp., Korea) on a TP650 standard TaKaRa PCR Thermal Cycler Dice (TaKaRa Bio Inc., Shiga, Japan). Amplified DNAs were subjected to electrophoresis in 1.0\% agarose gel and the single bands showing different amounts of PCR products were cut and purified using Zymo DNA Clean and Concentrator ${ }^{\mathrm{TM}}$ Kit (Promega Corp., Madison, WI, USA). The purified PCR products were then sequenced on an Applied Biosystems DNA Sequencer (model ABI 3700). The resulting sequences were compared to the GenBank database using the NCBI BLAST analysis.

For examining microbial inoculum densities in MA and $\mathrm{MB}$, the microbial products were suspended in sterilized distilled water (SDW), serially diluted, and then plated on
BHI agar. After 2 or 3 days, colonies formed on agar were counted and converted to colony-forming units (CFU) per gram of the products. Three replications were used for each microbial product.

Inhibitory activity of the bacteria isolated from the microbial fungicides against the mycelia growth, zoosporangium formation, and zoospore release and germination of the pathogen. The pathogen isolate was cultured on V8 juice agar at $25^{\circ} \mathrm{C}$ for 4 days, and mycelial plugs were cut with a cork borer ( $7 \mathrm{~mm}$ in diameter), which were placed on the center of fresh V8 juice agar. Two bacterial isolates each from MA and MB were cultured on nutrient agar (NA) at $28^{\circ} \mathrm{C}$ for 2 days, into which SDW was poured and scraped with a cotton swab to make bacterial suspensions. These bacterial suspensions were diluted with SDW to adjust the bacterial concentrations of $1 \times 10^{8} \mathrm{CFU} / \mathrm{ml}\left(\mathrm{OD}_{600}=0.8\right)$ using a spectrophotometer. The bacterial suspensions were spotted on four sites in a Petri plate at equal spacing around the perimeter with $3.0 \mathrm{~cm}$ apart from the mycelia plug of the pathogen placed on the center. They were incubated at $25^{\circ} \mathrm{C}$ and the inhibition of the pathogen mycelial growth was measured at 5 days later. Each treatment had four replications.

For the assessment of inhibitory effect of antagonistic microbes isolated from $\mathrm{MA}$ and $\mathrm{MB}$ on zoosporangium formation, a circular area of agar was removed from the margins of 4-day-old cultures of $P$. capsici grown on V8 juice agar with a cork borer ( $7 \mathrm{~mm}$ in diameter), and 3 mycelial plugs were placed in clarified fresh V8 juice in a Petri plate $(65 \mathrm{~mm} \times 10 \mathrm{~mm})$. The culture plates were incubated at $25^{\circ} \mathrm{C}$ for $24 \mathrm{~h}$ to allow young mycelial colonies to develop. The broth in the culture plates was replaced by SDW and the mycelial mats were rinsed in SDW three times for $15 \mathrm{~min}$ each. Then the mycelial mats were flooded with $5 \mathrm{ml}$ of the bacterial suspensions of various concentrations (SDW, $10^{4}, 10^{5}, 10^{6}, 10^{7}$, and $10^{8} \mathrm{CFU} / \mathrm{ml}$ ) and incubated at $25^{\circ} \mathrm{C}$ for $48 \mathrm{~h}$ about $20 \mathrm{~cm}$ beneath a blue fluorescent light to induce the zoosporangium formation. SDW-treated mycelial mats served as controls. The number of zoosporangia formed on the mycelia mats in a Petri plate was counted under a Zeiss Axioplan-2 research microscope with a $10 \times$ objective. Each treatment was replicated six times.

To observe the effect of antagonistic microbes isolated from $\mathrm{MA}$ and $\mathrm{MB}$ on zoospore release from zoosporangia, P. capsici grown on $\mathrm{V} 8$ juice agar at $25^{\circ} \mathrm{C}$ for 4 days were scraped with a glass spreader, and incubated for $24 \mathrm{~h}$ at $25^{\circ} \mathrm{C}$ beneath a blue fluorescent light to induce the production of zoosporangia as mentioned above. Agar plugs, on which the zoosporangia were induced, were cut with a cork borer ( $7 \mathrm{~mm}$ in diameter), and 3 plugs were placed at even 
distances from one another in a Petri plate $(65 \mathrm{~mm} \times 10$ $\mathrm{mm}$ ) containing $5 \mathrm{ml}$ of each microbial suspension of various concentrations (SDW, $10^{4}, 10^{5}, 10^{6}, 10^{7}$, and $10^{8} \mathrm{CFU} /$ $\mathrm{ml}$ ). Release of zoospores from the zoosporangia was induced by chilling the Petri plates at $4^{\circ} \mathrm{C}$ for $60 \mathrm{~min}$, after which they were transferred to $25^{\circ} \mathrm{C}$ to make zoospore suspensions. The zoospore suspensions were transferred to Eppendorf tubes $1 \mathrm{~h}$ after the treatment, and the number of zoospores were counted with a haemacytometer. Each treatment was replicated three times and SDW-treated Petri plates served as controls.

For evaluation of inhibitory activity of the microbes isolated from MA and $\mathrm{MB}$ on zoospore germination of $P$. capsici, zoospore suspensions of $P$. capsici (ca. $10^{5}$ zoospores $/ \mathrm{ml}$ ) released from zoosporangia in SDW in the above experiment were mixed with an equal volume of culture suspension of each concentration of bacterial cells $\left(10^{4}-10^{8} \mathrm{CFU} / \mathrm{ml}\right)$, and then $10 \mu \mathrm{l}$ aliquots of the mixture was dropped on V8 juice agar plates, which were incubated for $3 \mathrm{~h}$ at $25^{\circ} \mathrm{C}$. Zoospore suspensions mixed with the equal volume of SDW served as controls. The number of zoospores germinated were examined and counted under the microscope. Each treatment was replicated seven times.

Effect of microbial fungicides on the control of phytophthora blight of pepper in potted soil. Chili pepper seedlings (variety Bu-Gang) grown in plastic posts of 6-cm diameter filled with $500 \mathrm{~g}$ sterilized sand and potting mixtures were treated with the microbial fungicides by irrigating $50 \mathrm{ml}$ of $\mathrm{MA}$ and $\mathrm{MB}$ at the recommended concentrations (MA: $5.0 \mathrm{ml} / \mathrm{L}$, MB: $3.3 \mathrm{ml} / \mathrm{L}$ as diluted in SDW) firstly 40 days and secondly 47 days after planting. SDW-treated pots served as controls. The pathogen was inoculated into each pot 6 days after the second treatment of the microbial fungicides with $8 \mathrm{ml}$ of the pathogen zoospore suspension $\left(1 \times 10^{4}\right.$ zoospores $\left./ \mathrm{ml}\right)$. The pots were arranged in randomized block design on a bench in a greenhouse at $25 \pm 2^{\circ} \mathrm{C}$. Pots were watered daily to field capacity. Each treatment was replicated ten times. Symptom development was examined daily. Disease severity on above ground plant parts was evaluated at 5 days after inoculation using a scale modified from Ristaino (1990) as follows: $0=$ no visual disease symptoms, $1=$ leaves slightly wilted with brownish lesions beginning to appear on stem, $2=30-50 \%$ of entire plant diseased, $3=50-70 \%$ of entire plant diseased, $4=70-90 \%$ of entire plant diseased, $5=$ entire plant dead.

Statistical analysis. Data from the experiments were analyzed by analysis of variance (ANOVA) using SAS for Windows, V.9.1 (SAS Institute, Cary, NC, USA) and the mean values were compared using the Duncan's multiple range test (DMRT) at $P=0.05$.

\section{Results}

Evaluation of the microbial fungicide commodities. Analysis of $16 \mathrm{~S}$ rDNA sequencings for the microbes isolated from the microbial fungicides showed that they were matched to Paenibacillus polymyxa for MA (99\% identical with maximum score of 2375 to numerous NCBI accessions including Acc No. EU430119.1, GU328684.1, GQ849013.1, etc., and to Bacillus subtilis for MB (100\% identical with maximum score of 2145 to $14 \mathrm{NCBI}$ accessions including Acc. No. HM224387.1, GQ452909.3, HM055610.1, etc. (Data not shown). This indicates that both MA and MB contain the same microbial species marked on the products of the microbial fungicides. Inoculum densities of the microbes contained in the microbial fungicides examined in this experiment were revealed to be $9.9 \times 10^{7} \mathrm{CFU} / \mathrm{ml}$ for $\mathrm{MA}$ and $1.3 \times 10^{8} \mathrm{CFU} / \mathrm{ml}$ for $\mathrm{MB}$, which appeared to exceed the microbial concentrations that were marked on the products $\left(1 \times 10^{7} \mathrm{CFU} / \mathrm{ml}\right.$ for MA and $5 \times 10^{6} \mathrm{CFU} / \mathrm{ml}$ for $\mathrm{MB}$, respectively.

Inhibitory activity of the bacteria isolated from the microbial fungicides against the mycelia growth, zoosporangium formation, and zoospore release and germination of the pathogen. The microbes from $\mathrm{MA}$ and $\mathrm{MB}, P$. polymyxa and $B$. subtilis (hereafter termed as MAP and MBB), showed different inhibitory activity against the mycelia growth of $P$. capsici; no significant reduction of the mycelia growth for MAP but significant for MBB (Fig. 1). The inhibition rates of the pathogen mycelia growth were significantly higher for MBB (inhibition rate of 33\%) than for MAP (inhibition rate of $11 \%$ ).

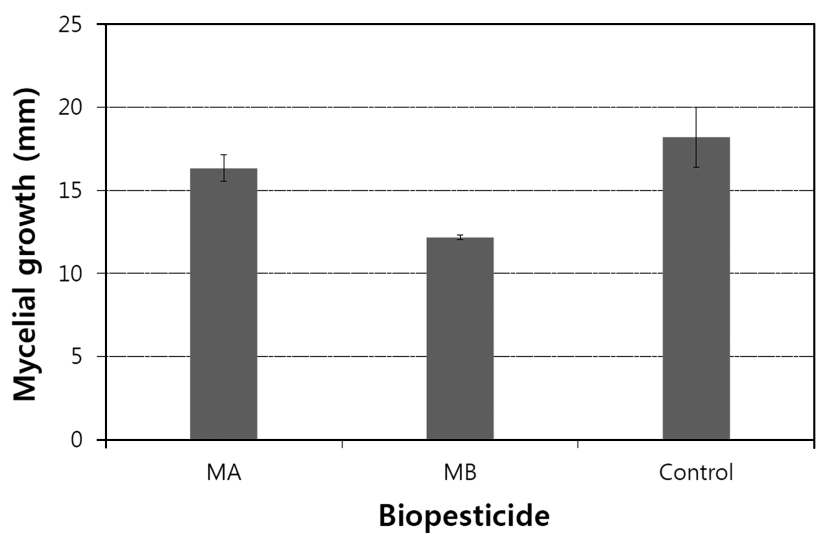

Fig. 1. Effect of antagonistic microbes from microbial fungicides MA and MB on the inhibition of mycelia growth of Phytophthora capsici. Vertical bars and lines are means and standard deviations of 4 replications. 


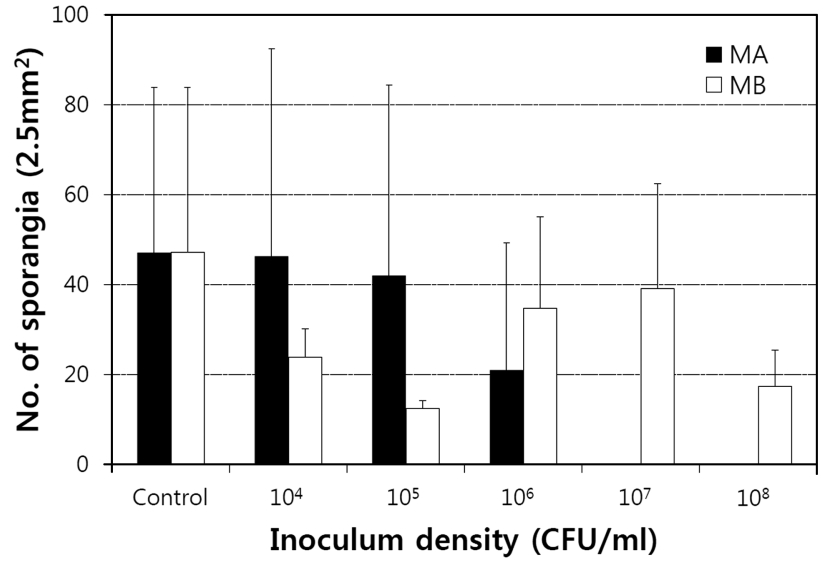

Fig. 2. Effect of antagonistic microbes from microbial fungicides $\mathrm{MA}$ and MB on the inhibition of zoosporangial formation of Phytophthora capsici. Vertical bars and lines are means and standard deviations of 6 replications.

The inhibitory activity of MAP and MBB against zoosporangium formation varied depending on the inoculum densities (Fig. 2). For MAP, the inhibitory effects on zoosporangium formation increased with the increase of inoculum densities from $1 \times 10^{5} \mathrm{CFU} / \mathrm{ml}$. No zoosporangium was formed at the inoculum densities of $1 \times 10^{7} \mathrm{CFU} / \mathrm{ml}$ and $1 \times 10^{8} \mathrm{CFU} / \mathrm{ml}$ of MAP. On the other hand, the inhibitory effects on the zoosporangium formation fluctuated, showing little consistency to its inoculum densities. Totally MAP was higher in the inhibition of zoosporangium formation than MBB.

Zoospore release from zoosporangia was significantly inhibited by both MAP and MBB (Fig. 3). It was dependent on the inoculums densities for MAP, showing the zoospore release decreased rapidly at higher inoculum densities

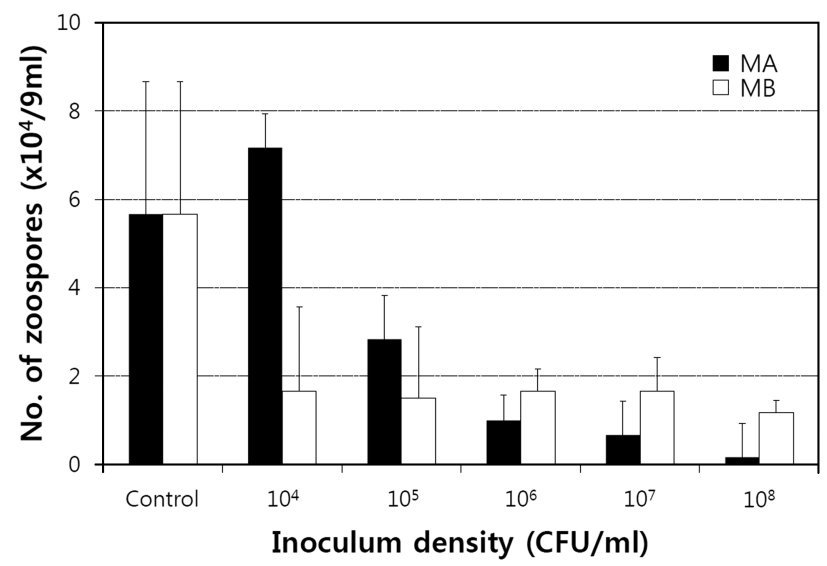

Fig. 3. Effect of antagonistic microbes from microbial fungicides $\mathrm{MA}$ and $\mathrm{MB}$ on the inhibition of zoospore release from zoosporangia of Phytophthora capsici. Vertical bars and lines are means and standard deviations of 3 replications.

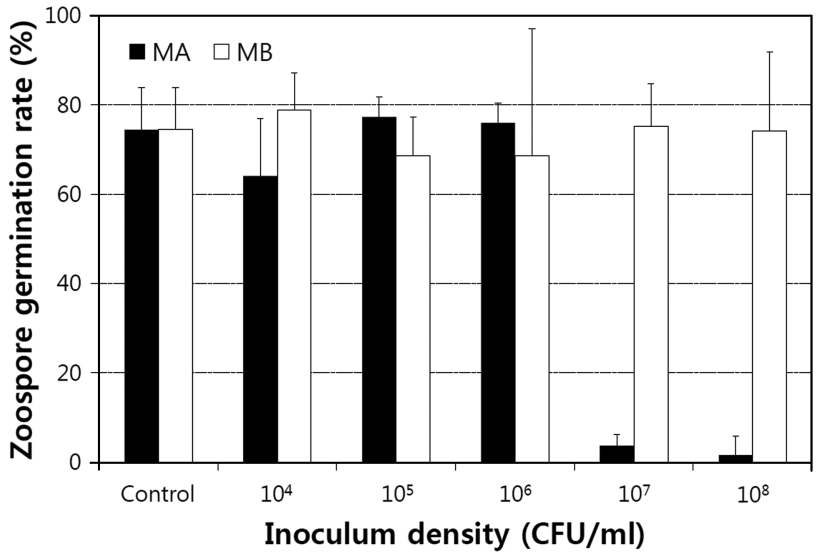

Fig. 4. Effect of antagonistic microbes from microbial fungicides $\mathrm{MA}$ and $\mathrm{MB}$ on the inhibition of zoospore germination of Phytophthora capsici. Vertical bars and lines are means and standard deviations of 7 replications.

especially from $1 \times 10^{5} \mathrm{CFU} / \mathrm{ml}$, while for MBB, the inhibitory effect was not influenced by the inoculum densities. There was also no significant difference in the inhibition of the zoospore release between the two microbes.

The zoospore germination rate in the no treatment control was about $76 \%$. No significant inhibition of zoospore germination was noted by $\mathrm{MBB}$, while it was greatly inhibited by MAP at the higher inoculum densities of $1 \times 10^{7} \mathrm{CFU} / \mathrm{ml}$ and $1 \times 10^{8} \mathrm{CFU} / \mathrm{ml}$, in which the zoospore germination rates were reduced to $3.7 \%$ and $1.6 \%$, respectively (Fig. 4).

Effect of microbial fungicides on the control of phytophthora blight of pepper in potted soil. The phytophthora blight of pepper began to develop from 3 days after inoculation. At 5 days after inoculation, 9 out of 10 pepper plants

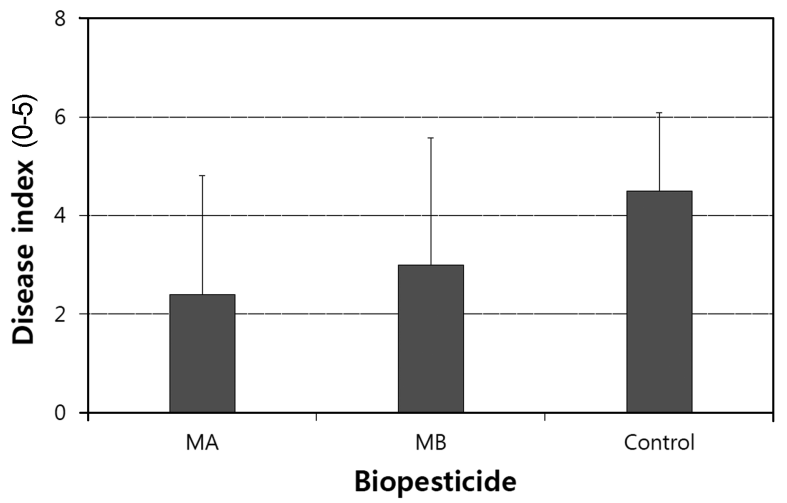

Fig. 5. Effect of microbial fungicides MA and MB on the control of phytophtora blight in chili pepper caused by Phytophthora capsici. Vertical bars and lines are means and standard deviations of 10 replications. 
were dead, showing an average disease index (DI) of 4.5. On the other hand, the treatments of MA and MB reduced the disease severities to DI 2.4 and DI 3.0, respectively, for which the control effects were corresponding to $46.7 \%$ and $33.3 \%$, respectively. However, statistical analysis showed no significant difference at $P=0.05$ between the treatments and the inoculated control.

\section{Discussion}

In our study, the microbial fungicides MA and MB, which were developed as biocontrol agents against plant diseases caused by Phytophthora spp., contained proper microbial species with proper and even exceeding amounts of microbial populations, compared to those marked on the microbial products. Contamination of the microbes other than the marked bacterial species was not observed in this experiment. These results suggest the microbial products have maintained a reliable quality as registered commercial biocontrol commodities. The examination of the other microbial products presently registered as biofungicides (containing antagonistic bacteria) also revealed that they all contained proper microbial species and amounts as marked on the products. Thus, all microbial fungicides registered in Korea at present may be all qualified at least as commercial microbial fungicides (Koh et al., unpublished data).

The microbial fungicides (MA and MB) examined in our study showed no significant reduction of the pepper disease caused by $P$. capsici, compared to the inoculated control. However, in detailed examination, MA and MB somewhat reduced the pepper disease, and MA was more effective than MB. In comparison of the microbes (MAP and MBB) from MA and $\mathrm{MB}$ in the antagonistic activities against $P$. capsici, MAP was effective prominently against zoospore germination, while MBB only was effective against mycelia growth of the pathogen. Some effectiveness of MAP and MBB was noted in the inhibition of zoosporangium formation and zoospore release from zoosporangia; however, no such large difference between MAP and MBB was noted as in the inhibition of zoospore germination and mycelia growth. Considering the effectiveness of the disease control, these results suggest that the disease control efficacy would be more attributable to the inhibition of zoospore germination than mycelia growth of $P$. capsici. This is probably because Phytophthora pathogens start the infection cycle by zoospore germination but not by mycelial growth (Agrios, 2005). Zoosporangium formation and zoospore release also may have influenced on the disease development, as they affect the inoculum potentials qualitatively and quantitatively (Kim et al., 2009). Therefore, MA and MB may exert the disease control by inhibiting multiple sites in the life cycle of the pathogen with differ- ential efficacies, consequently making MA more effective than MB in the biological control of the pepper disease.

Bacillus and relatives (including Paenibacillus) form endospores that are resistant to environmental stresses such as desiccation, whose characteristics are useful in producing commercial microbial agents with a long shelf-life compared with pseudomonad-based biofungicides (Chanway, 2002; Walker et al., 1998). Their mode of action in antagonism is mainly antibiosis by producing many antagonistic substances, and sometimes competition, but rarely hyperparasitism (Chanway, 2002; Dijksterhuis et al., 1999; Haggag, 2007; Haggag and Timmusk, 2008; Helbig, 2001; Khan et al., 2008). Our study, however, suggests that antagonistic microbes even with the same antibiosis mode of action may target different points in the life cycle of a pathogen, presumably resulting in different control efficacies of the specific disease caused by the pathogen. Therefore, it is required to examine the targeting points in the pathogen's life cycle as well as the action mode of antagonistic microorganisms in the development of efficient microbial fungicides.

\section{Acknowledgement}

This study was carried out with the financial support from the Office of Rural Development Administration, Republic of Korea.

\section{References}

Agrios, G. N. 2005. Plant pathology. $5^{\text {th }}$ ed. Elsevier Academic Press, London, UK. 922 pp.

Brosius, J., Palmet, M. L., Kennedy, P. J. and Noller, H. F. 1978. Complete nucleotide sequence of a 16S ribosomal RNA gene from Escherichia coli. Proc. Natl. Acad. Sci. USA 75:48014805.

Chanway, C. P. 2002. Chapter 15. Plant growth promotion by Bacillus and relatives. In: Applications and systematic of Bacillus and relatives, ed. by R. Berkeley, M. Heyndricks, N. Logan and P. De Vos, pp. 219-235. Blackwell Science, Ltd., Oxford, UK.

Dijksterhuis, J., Sanders, M., Gorris, L. G. M. and Smid, E. J. 1999. Antibiosis plays a role in the context of direct interaction during antagonism of Paenibacillus polymyxa towards Fusarium oxysporum. J. Appl. Microbiol. 86:13-21.

Haggag, W. M. 2007. Colonization of expolysaccharide-producing Paenibacillus polymyxa on peanut roots for enhancing resistance against crown rot disease. Afr. J. Biotechnol. 6: 1568-1577.

Haggag, W. M. and Timmusk, S. 2008. Colonization of peanut roots by biofilm-forming Paenibacillus polymyxa initiates biocontrol against crown rot disease. J. Appl. Microbiol. 104:961969. 
Helbig J. 2001. Biological control of Botrytis cinerea Pers. ex Fr. in strawberry by Paenibacillus polymyxa (Isolate 18191). J. Phytopathol. 149:265-273.

Hwang, B. K. 2002. Studies of resistance of pepper to phytophthora blight and its control. Res. Plant Dis. (in Korean) 8:131145.

Hwang, B. K. and Kim, C. H. 1995. Phytophthora blight of pepper and its control in Korea. Plant Dis. 79:221-228.

Khan, Z., Kim, S. G., Jeon, Y. H., Khan, H. U., Son, S. H. and Kim, Y. H. 2008. A plant growth promoting rhizobacterium, Paenibacillus polymyxa strain GBR-1, suppresses root-knot nematode. Bioresour. Technol. 99:3016-3023.

Kim, B.-S. 2004. Diagnosis and control of important diseases in pepper. In: Molecular genetics and breeding of chili pepper in Korea (in Korean), ed. by B. D. Kim, H. G. Park and Y. H. Kim, pp. 147-180. Center for Molecular Genetics and Breeding Research, Seoul National University, Seoul, Korea.

Kim, S. G. and Kim, Y. H. 2009. Histological and cytological changes associated with susceptible and resistant responses of chili pepper root and stem to Phytophthora capsici infection. Plant Pathol. J. 25:113-120.

Kim, S. G., Khan, Z., Jeon, Y. H. and Kim, Y. H. 2009. Inhibitory effect of Paenibacillus polymyxa GBR-462 on Phytophthora capsici causing phytophthora blight in chili pepper. J. Phyto- pathol. 157:329-337.

Ristaino, J. B. 1990. Intraspecific variation among isolates of Phytophthora capsici from pepper and cucurbit fields in North Carolina. Phytopathology 80:1253-1259.

Ristaino, J. B. and Johnston, S. A. 1999. Ecologically based approaches to management of phytophthora blight on bell pepper. Plant Dis. 83:1080-1089.

Walker, R., Powell, A. A. and Seddon, B. 1998. Bacillus isolates from the spermosphere of peas and dwarf French beans with antifungal activity against Botrytis cinerea and Pythium species. J Appl. Microbiol. 84:791-801.

Weisburg, W., Barns, S. M., Pelletier, D. A. and Lane, D. J. 1991. 16S ribosomal DNA amplification for phylogenetic study. $J$. Bacteriol. 173:697-703.

Whipps, J. M. and Davies, K. G. 2000. Chapter 8. Success in biological control of plant pathogens and nematodes by microorganisms. In: Biological control: Measures of success, ed. by G. Gurr and S. Wratten, pp. 231-269. Kluwer Academic Publishers, London, UK.

Whipps, J. M. and McQuiken, M. P. 2009. Chapter 3. Biological control agents in plant disease control. In: Disease control in crops: Biological and environmentally friendly approaches, ed. by D. Walters, pp. 27-61. A John Wiley \& Sons, Ltd., Oxford, UK. 